\author{
Marquette University \\ e-Publications@Marquette
}

College of Nursing Faculty Research and

Publications

Nursing, College of

2019

\title{
A Historical Review of the Catholic Scientists Who Answered the Call of Humanae vitae
}

Richard J. Fehring

richard.fehring@marquette.edu

Follow this and additional works at: https://epublications.marquette.edu/nursing_fac

Part of the Nursing Commons

\section{Recommended Citation}

Fehring, Richard J., "A Historical Review of the Catholic Scientists Who Answered the Call of Humanae vitae" (2019). College of Nursing Faculty Research and Publications. 724.

https://epublications.marquette.edu/nursing_fac/724 


\title{
A Historical Review of the Catholic Scientists Who Answered the Call of Humanae vitae
}

\author{
Richard J. Fehring
}

* Fifty years ago, Pope Paul VI called on scientists to "explain more thoroughly the various conditions favoring a proper regulation of birth" and to study what he called "sufficiently secure" methods of natural fertility regulation, what we refer today as methods of Natural Family Planning (NFP). ${ }^{1}$ In today's parlance scientists would interpret the words "secure methods" as "effective methods" of NFP for pregnancy avoidance. Furthermore, scientific standards would dictate the need for scientists to provide an evidence base (i.e., multiple highlevel evidence studies) for effective methods of NFP. This challenge also means, from a science perspective, developing and providing "sufficient" evidence for effective NFP methods for women who are experiencing what are called special reproductive situations, such as the postpartum transition to fertility or during the transition to menopause, and for couples wishing to achieve a pregnancy.

Paul VI also called on physicians and health professionals to provide couples with the necessary knowledge to use NFP for their family planning needs. ${ }^{2}$ This essay, however, is not about the provision of NFP services or analyzing NFP effectiveness studies. Rather, my focus is on the scientists who responded to Paul VI's call not only to develop NFP methods but also to provide the evidence for their effectiveness, as well as to highlight the Catholic scientists who heard and answered that call.

This essay will follow a historical timeline of the Church's call for scientific research: pre-Humanae vitae era, which includes the papacies of Pius XI (19221939) and Pius XII (1939-1958), the Papal Birth Control Commission (19631966) and writing of Humanae vitae (1966-1968); and the post-Humanae vitae era (1968-2005). The pre-Humanae vitae era will include Catholic scientists' responses to Pope Pius XI's encyclical Casti connubii (1930) and the writings of Pope Pius XII on natural birth regulation and contraception. The post-Humanae vitae era will end with the pontificate of Pope John Paul II. This essay is essentially an historical overview of the interaction between the Catholic Church, the

1 Pope Paul VI, Encyclical Letter Humanae vitae (Boston: Pauline Books, 1968), 24.

2 Pope Paul VI, Humanae vitae, 27. 
pope's call (and sometimes pleading) for scientific help, and the Catholic scientists' responses. ${ }^{3}$

Before beginning the discussion, however, there is a need to define what a scientist is and identify the characteristics of a Catholic scientist. In this essay, a scientist is one who has the proper education to develop, propose, obtain significant funding, carry out research, and publish findings in peer-reviewed scientific journals. This usually requires a person to have at least a $\mathrm{PhD}$ in a discipline of science and/ or be a medical doctor (MD) who has research experience and knowledge. Those degrees are a minimum. A scientist is one who also has a consistent track record of research and publications in peer-reviewed journals in an area of research. The most active scientists are usually those who have post-doctoral fellowships, the ability to write successful research grant proposals and obtain significant grant money to carry out research, and the ability to gather and work with a research team. Without these qualifications (unless applying for a graduate training grant), a scientist will not receive significant federal or foundation funding. In today's world, a scientist usually works with a team of scientists that includes a biostatistician who helps to analyze data with sophisticated statistical methods.

If a research scientist develops and wishes to test the effectiveness of a new method of NFP in helping couples avoid an unintended pregnancy, then that scientist will need institutional research human rights approval with yearly updates, reapplication of human rights approval every three years, registration to the federal government for clinical trials with frequent reports, a well-defined data safety plan certified that he or she has met the research design criteria, and yearly federal grant reports. Furthermore, federal grants are usually not provided to individuals but rather to research and academic institutions that have the resources to support such research endeavors.

Another important aspect or characteristic of a scientist is one who feels called to research a significant topic area in science. In other words, a scientist has a passion for an area of research and is consistent in researching that area. This passion could come from personal experience (e.g., suffering from infertility), an idea from a peer or colleague, significant research areas delineated by professional organizations, or for others, a sense of purpose, faith, or personal calling from God guiding one in that direction. For those scientists who are researching methods of NFP, that call, and the subsequent research might also mean suffering in some way. Suffering could come in the form of ridicule by peers, rejected articles for publication, rejected grant proposals for research, failing to be granted tenure, not being promoted, or not receiving pay raises. A passionate researcher, or one who feels called, will accept the rejection but continue to work on his or her area of research and find ways to work with colleagues who are fair-minded.

Although there are other areas of research (besides investigating the effectiveness of NFP methods) that the encyclical Humanae vitae lends itself to research,

3 It should be noted that even the post-Casti connubii and post-Pius XII NFP scientists were active well into the post-Humanae vitae era. 
such as the psychological effects of using NFP, the effects of NFP on marital dynamics, and the pursuit of moral methods of managing infertility, this essay will focus on the Church's call to develop and research methods of NFP and provide examples of early scientists who contributed to the science of NFP.

\section{The Church's Call to Scientists Pre-Humanae vitae (1930-1966)}

Paul VI was not the first pope to call on scientists to develop and research natural methods of birth regulation and not the first pope to condemn the use of the new hormonal birth control pill for family planning purposes. The Catholic Church slowly developed its understanding of what we now refer to as NFP in the modern period. It began with a tentative approval of natural birth regulation methods as an ethical support for marriage. The methods and morality of abstaining from sexual intercourse during the estimated fertile phase of the woman's menstrual cycle to avoid pregnancy was addressed by leaders in the Catholic Church in the late 1800 s. $^{4}$ However, it was not until Pius XI's promulgation of Casti connubii on December 31, 1930, that the Catholic Church formally approved the use of periodic sexual abstinence during the woman's fertile phase. ${ }^{5}$

At that time, there was little support for the development, research, and promotion of natural methods of birth regulation within the medical profession and the Church. There was much skepticism concerning the various theories about the infertile time of the menstrual cycle-many clergy were still advocating inaccurate methods of avoiding the fertile phase of the menstrual cycle. ${ }^{6}$ Priests were not encouraged to promote natural methods of birth regulation, but, rather, only to suggest their use in the confessional when there were grave reasons for their use. Furthermore, there was much doubt among Catholic physicians and the National Federation of Catholic Physicians (now called the Catholic Medical Association) whether these methods actually worked and whether they were moral. ${ }^{8}$

\section{NFP Scientists during Pius XI's Papacy (1922-1939)}

About the same time of Pius XI's encyclical Casti connubii, the first effective calendar-based methods of natural birth regulation were being researched, presented at medical conferences, and made known to the European, Japanese, and

4 Sacred Penitentiary 1853 and 1880, in Natural Family Planning: Nature's Way-God's Way, ed., Anthony Zimmerman (Milwaukee: DeRance, Inc., 1980), 228. Note that the methods proposed at that time were not accurate and would lead to unintended pregnancy.

5 Pope Pius Xl, Encyclical Letter Casti connubii, December 31, 1930 (New York: Paulist Press, 1941).

6 John T. Noonan, Jr., Contraception: A History of its Treatment by the Catholic Theologians and Canonists (Cambridge, Mass.: Harvard University Press, 1986), 438-475.

7 Leslie Tentler, Catholics and Contraception: An American History (1thaca, N.Y.: Cornell University Press, 2004). See also John D. Conway, What They Ask about The Rhythm (Notre Dame, Ind.: Ave Maria Press, 1956), 3-7.

8 Ethicus, "The Morality of the Use of the Safe Period," The Linacre Quarterly 1, no. 2 (March 1933): 23-26. 
Unites States populations. ${ }^{9}$ Dr. Kyusaku Ogino (Japan) and Dr. Herman Knaus (Austria) are the two individuals who have been credited with the discovery of the first usable and scientific methods of natural birth regulation. ${ }^{10}$ They independently (and in very different manners) discovered that ovulation preceded menstruation by about fourteen days.

Ogino was the head of gynecology at Takeyama Hospital in Negata, Japan. As a surgical gynecologist, he observed the ovaries of 118 of his patients during abdominal surgery. Based on the size and condition of the follicle or corpus luteum, he was able to determine roughly when ovulation occurred. He published his results in a Japanese scientific journal in $1923 .{ }^{11}$ Knaus, who was the head of an obstetrics and gynecology clinic at the German University in Prague, used a different approach to estimate the time of ovulation during the menstrual cycle. He injected a pituitary extract into women subjects and then recorded the activity of their uterine muscles. He noticed that before ovulation, the pituitary injection would cause uterine contractions but after ovulation, it did not. By conducting this research on a day-to-day basis, he was able to estimate the time of ovulation (based on the last day of uterine contractions) and, like Ogino, observed that ovulation preceded menstruation by about fourteen days. What became known as "Knaus's Law" stated that menstruation would follow ovulation by fourteen days. And, like Ogino, he developed a calendar formula for determining the fertile and infertile times of the woman's menstrual cycle. Knaus published his findings in a German scientific journal in $1932 .^{12}$

Despite the work of Ogino and Knaus, the calendar-based methods of natural birth regulation were actually first developed and popularized in Europe by a Catholic physician from the Netherlands, Dr. John Smulders, and by a Catholic professor of obstetrics and gynecology at Loyola University in Chicago, Dr. Leo Latz. Smulders based his calendar method on the work of Ogino and Dutch gynecologist Dr. Theodoor Hendrik van de Velde. ${ }^{13}$ Smulders discussed his method in a book published in 1930 by the Dutch Roman Catholic medical association. Latz, actually studied the Knaus's research and later the Ogino research and developed his calendar method. He published his research and method for natural birth regulation in a 1932 book titled The Rhythm of Sterility and Fertility in Women. ${ }^{14}$

9 Kyusaku Ogino, Conception Period of Women (Harrisburg: Medical Arts Publishing Company, 1934), 79-80; Herman Knaus, Periodic Fertility and Sterility in Woman: A Natural Method of Birth Control (Vienna: Wilhelm Maudrich, Publisher, 1934).

10 Ogino, Conception Period of Women, 79-80.

11 Kyusaku Ogino, "Period of Ovulation, Relation Between Corpora Lutea and Cyclical Changes in the Uterine Endometrium; Cyclical Changes in the Uterine Endometrium and Fertile Time," Japanese Gynecological Journal 19 (1924): 6.

12 See Herman Knaus, Periodic Fertility and Sterility in Woman.

13 Jean Nicolas Joseph Smulders, Peeriodieke Onthounding in Het Huwelijk. Methode Ogino-Knaus (Nijmegen-Utrecht: Dekker \& Van de Vegt,1930).

14 Leo Latz, The Rhythm of Sterility and Fertility in Women (Chicago: Latz Foundation, 1932). 
Latz also conducted and published an effectiveness study on the use of the calendar method for avoiding pregnancy. ${ }^{15} \mathrm{He}$ provided evidence of no pregnancies from over 54,000 acts of intercourse during the infertile times indicated by his method. Over the next twenty years, his foundation (The Leo Latz Foundation) sold more than six-hundred thousand copies of his book, in which he declared that his simple method could be taught by physicians, professional nurses, or social workers in a twelve-minute office session. ${ }^{16}$ The title of Latz's book most likely supplied the title "Rhythm Method" for calendar-based methods, a term still commonly (and erroneously) used for all NFP methods by health professionals and the lay public. Another famous (or infamous) Catholic physician from Harvard University, Dr. John Rock, founded the first Rhythm Clinic in the United States in the 1930s to teach Catholic couples. ${ }^{17}$ Unfortunately, Rock was later responsible (along with another physician from Puerto Rico), for obtaining Food and Drug Administration approval for the first hormonal birth control pill (Enovid) in the United States in 1960.

During the 1930s through the mid-1950s, the Rhythm Method was one of the most popular methods of family planning among US women and Catholic women in particular. Upward of 30 percent of women of reproductive age, and 55 percent of Catholic women used calendar-based methods well into the 1950s. ${ }^{18}$ With the advent of the hormonal birth control pill, that statistic changed dramatically. The ease of use of birth control pills, coupled with anecdotal evidence of couples unintentionally becoming pregnant with the Rhythm Method, led to a decline in use of calendar-based methods. Interestingly, more women of reproductive age in the United States currently use "Rhythm" than the so-called modern methods of NFP, which rely on cervical mucus and basal body temperature. ${ }^{19}$ Furthermore, efforts have been renewed to investigate calendar-based methods using a careful scientific approach..$^{20}$

15 Leo J. Latz and E. Reiner, "Natural Conception Control," Journal of the American Medical Association 105, no. 16 (October 19, 1935): 1241.

16 For his work on natural birth regulation, Dr. Latz was dismissed from his position at Loyola University and his book lost its imprimatur from Chicago Cardinal George Mundelein. It was considered scandalous that married couples should have the information that his book provided. Latz continued teaching about his work and NFP at three Catholic nursing programs in Chicago.

17 John Rock, The Time Has Come (New York: Avon Books, 1963).

18 Charles F. Westoff and N. R. Ryder, "Conception Control among American Catholics," in Catholics/U.S.A.; Perspectives on Social Change, eds. W. T. Liu and N. J. Pallone (New York: John Wiley \& Sons, 1970), 257-268.

19 K. Daniels, J. Daugherty, and J. Jones, "Current Contraceptive Status Among Women Aged 15-44: United States, 2011-2013," NCHS Data Brief 173 (December 2014): 1-7.

20 Researchers at Georgetown University's Institute for Reproductive Health have developed a fixedday, calendar-based method of NFP bead system and mobile phone app used to help couples track fertility. The lnstitute for Reproductive Health researchers found this method of natural birth regulation to be comparable in efficacy to barrier methods of contraception. These researchers are currently investigating the effectiveness of a new calendar-based method of NFP based on day specific probabilities of pregnancy and the use of a cell phone app called Dynamic Optional Timing or DOT. See D. Li, L. Heyer, V. H. Jennings, C. A. Smith, and D. B. Dunson, "Personalised Estimation of a Women's Most Fertile Days," The European Journal of Contraception \& Reproductive Health Care 21, no. 4 (2016): 323-328. 
In 1935, a Catholic parish priest in Germany by the name of Father Wilhelm Hillebrand was teaching his married parishioners the Knaus Calendar method of NFP. ${ }^{21}$ A number of the couples he taught became pregnant although that was not their intention (i.e., supposedly they only had intercourse during what the Knaus formula indicated was the infertile time). This disturbed Hillebrand and he sought help from his two physician brothers. One of his brothers was familiar with the early temperature work by Van de Velde and shared this information with him. Hillebrand devised a method in which the couple would use basal body temperature readings (the first morning measurement of body temperature before rising and activity), along with the calendar formulas to determine the fertile and infertile times of the menstrual cycle. Hillebrand is credited as the first person to develop the use of basal body temperature (BBT) along with the calendar methods as a natural means of birth regulation. In 1959, he was awarded an honorary doctorate for his work with body temperature as applied to family planning from the University of Berlin, Germany. Later, in 1977, Dr. Rudolf Vollman would credit Hillebrand as the first person to use the term "Natural Family Planning" in his writings. ${ }^{22}$

The beauty of the Rhythm or calendar-based methods is that they are simple to use and teach. As noted above, it was not until the introduction of hormonal contraceptives in late 1950s that the Rhythm Method of family planning fell into disfavor. In fact, in 1936, Dr. Carl Hartman, ${ }^{23}$ a renowned obstetrician and gynecologist from Johns Hopkins Medical School Department of Embryology, stated that the calendar-rhythm methods of family planning were as effective as any available contraceptive at that time. ${ }^{24}$

NFP Scientists during Pius XII's Papacy (1939-1958)

It was not until 1951 when Pius XII gave an address to the Italian Catholic Union of Obstetrical Nurses that the use of NFP was elevated to something more than a topic to be mentioned quietly in the confessional. ${ }^{25}$ Pius XII provided a mandate to these nurses: they should not only understand and provide natural methods of birth regulation but also know and defend the moral law. In the same address,

21 Rudolf Vollman, "Foreword," in Natural Family Planning: Introduction to the Methods, ed. Clara R. Ross (Washington, D.C.: The Human Life Foundation, 1977), 1-5.

22 Vollman, "Foreword," in Natural Family Planning: Introduction to the Methods, 1-5.

23 C. G. Hartman, Time of Ovulation in Women (Baltimore: The Williams \& Wilkins Co., 1936).

24 It is commonly expressed that the newer methods of NFP (mucus only and mucus plus temperature, etc.) are more effective than the Calendar Rhythm Method. However, in the 1990s, Robert Kambic, a Catholic scientist at the time from Johns Hopkins University involved with NFP science for many years, conducted a meta-analysis of the Rhythm Method studies and found that the typical-use effectiveness of the method was around 15 unintended pregnancies per 100 over twelve months of use. This unintended pregnancy rate is well within the unintended pregnancy rates found with many of the studies conducted with the more modern methods of NFP. See Robert T. Kambic and Virginia Lamprecht, "Calendar Rhythm Efficacy: A Review," Advances in Contraception 12, no. 2 (1996):123-128.

25 Pope Pius X11, Address to Italian Catholic Union of Midwives (October 29, 1951) in Natural Family Planning: Nature's Way-God's Way, ed. Zimmerman, 229-230. 
he stated that these methods are to be used for serious reasons only, but that these reasons could include the woman's health (body and mind) and economic reasons. He even said there could be serious reasons why married couples could use natural birth regulation methods for the entirety of their reproductive lives.

Pius XII gave an address that same year to a congress on large families. At the congress, he stated that he hoped scientists would provide a secure base for the natural methods of birth regulation, that Catholic scientists should "bend their backs" to this problem, and that Catholic medical and research faculties should do all they can to meet this need and, in doing so, be eager to serve the Lord. ${ }^{26}$ In response to the development of the new anovulant progestational pill (i.e., hormonal birth control pill), Pius XII stated in a 1958 address to the Italian Congress of Hematologists that the use of such pills would be against the natural law and would be illicit. ${ }^{27} \mathrm{He}$ did note, however, that it would be licit to use these drugs to treat serious organic disorders. Physicians began using the new progestational pill to treat menstrual cycle irregularity but also realized that it suppressed ovulation and could be used as a hormonal contraceptive.

A number of scientists were stimulated by their faith and the pleadings of Pius XII and Catholic bishops for the need for better methods of natural birth regulation. Notable were the Catholic physician/scientists who researched and developed basal body temperature (BBT) as a method of NFP. Drs. Vollman (Switzerland and subsequently the United States), Peter J. Bartzen (United States), Gerhard Döring (Germany), and John Marshall (England) are notable for their work on the BBT. ${ }^{28}$ Vollman developed a charting system where he had women record not only temperature but also abdominal (ovulation) pain and changes in cervical mucus. He also studied the lengths and characteristics of the woman's menstrual cycle through phases of life. ${ }^{29}$ Marshall (1968), a neurologist, is credited with conducting the first prospective field trial of the effectiveness of BBT in avoiding pregnancy. ${ }^{30}$

Like Vollman, other physicians began independently to combine various biological indicators to aid women in the self-determination of the fertile and

\footnotetext{
26 Pope Pius XIl, Address to the National Congress of the Family Front and the Association of Large Families (November 26, 1951), in Natural Family Planning: Nature's Way-Gods Way, ed. Zimmerman, 231.

27 Pope Pius Xll, Address to Hematologists, in Natural Family Planning: Nature's Way-God's Way, ed. Zimmerman, 228.

28 P. J. Bartzen, "Effectiveness of the Temperature Rhythm System of Contraception," Fertility and Sterility 18, no. 5 (1967): 694-706; Gerhard K. Döring, "Detection of Ovulation by the Basal Body Temperature Method," in Proceedings of a Research Conference on Natural Family Planning, eds. William A. Uricchio and Mary Kay Williams (Washington, D.C.: The Human Life Foundation, 1972), 171-180: Gerhard K. Döring, "Uber die zuverlassigkeit der temperaturmethode zur empfangnisverhutung" [Reliability of the Temperature Method as a Means of Contraception], Deutsche Medizinische Wochenschrift 92, no. 23 (1967): 1055-1061. [English abstract: The Yearbook of Obstetrics and Gynecology, (Yearbook Medical Publisher), 354-355]; Rudolf. F. Vollman, "Assessment of the Fertile and Sterile Phases of the Menstrual Cycle," International Review of Natural Family Planning 1 (1977): 40-47; John Marshall, "A Field Trial of the Basal-Body Temperature Method of Regulating Births," Lancet 292, no. 7558 (July 6, 1968): 6-10.

29 Vollman, "Foreword" in Natural Family Planning: Introduction to the Methods, 1-5.

30 Marshall, "A Field Trial of the Basal-Body Temperature Method of Regulating Births," 6-10.
} 
infertile times of their menstrual cycles. ${ }^{31}$ Drs. Edward Keefe (United States) and Josef Rötzer (Austria) are considered early developers of the multiple indexed methods. In the United States, these are called the Sympto-Thermal Methods (STM). ${ }^{32}$ Keefe asked his women patients to check for temperature, cervical mucus elasticity, and internal cervix changes. He is noteworthy for developing the Ovulindex Thermometer that is specifically used for BBT. The thermometer is calibrated in tenths of a degree and thus more sensitive to detecting small changes in body temperature. In a short biography published by the NFP Program of the United States Conference of Catholic Bishops (USCCB), Keefe mentioned that as a Catholic physician, he was inspired by the pleadings of Pius XII to develop and research methods of NFP. ${ }^{33}$ Rötzer is known for developing the rule for identifying the full thermal shift (i.e., three higher basal body temperature readings than the preceding six).The World Health Organization adapted this rule as the standard means of determining the BBT shift. ${ }^{34}$ It is important to note that Rötzer's research influenced other physicians who would impact NFP education in the United States. Notably, Dr. Konald Prem, the department chair of obstetrics and gynecology at the University of Minnesota, was instrumental in helping John and Shiela Kippley develop the STM system based on Rötzer's work for the Couple to Couple League. ${ }^{35}$

Husband and wife team, Drs. John and Evelyn Billings (Australia) are considered the developers of the single fertility (mucus only) indicator model of NFP called the Ovulation Method or the Billings Ovulation Method ${ }^{\circledR}$ (also referred to as $\mathrm{OM}$ or $\left.\mathrm{BOM}^{\circledR}\right){ }^{36}$ In the 1950s, John Billings was asked by the archbishop of Melbourne to help improve the Rhythm Method. He studied the calendar method and BBT but also read some early studies on cervical mucus. Billings at first combined BBT with cervical mucus changes. When his wife, Evelyn, became actively involved with the development of the Ovulation Method in the 1960s, she realized that women were able to effectively track their fertile and infertile times of the cycle by the changes in their cervical mucus alone. Dr. James Brown, an endocrinologist, and Dr. Henry Burger, (Distinguished Scientist, Hudson Institute, Australia), helped to validate the method

31 Rudolf Vollman, The Menstrual Cycle (Philadelphia: W. B. Saunders, 1977).

32 Edward F. Keefe, "Self-Examination of the Cervix as a Guide in Fertility Control," International Review of Natural Family Planning 10, no. 4 (Winter 1986): 333-338; Josef Rötzer, "Further Evolution of the Sympto-Thermal Methods," International Review of Natural Family Planning 1, no. 2 (Summer 1977): $139-150$.

33 Edward Keefe with Theresa Notare, "NFP Pioneers, a Lifetime of Service," in NFP-Diocesan Activity Report 4 (1993): 4-5.

34 Josef Rötzer, Family Planning the Natural Way: A Complete Guide to the Symptom-Thermal MethodIncluding Questionnaires, Charts, and Reliable Procedures (Old Tappan, N.J.: Hleming H. Revell Co., 1981).

35 John Kippley, “The Couple to Couple League, Progress Through Teamwork." International Review of Natural Family Planning 1 (1977): 90-92.

36 Evelyn Billings and Ann Westmore, The Billings Method (New York: Ballantine, 2003); John J. Billings and Evelyn L. Billings, "Determination of Fertile and Infertile Days by the Mucus Pattern: Development of the Ovulation Method," in Proceedings of a Research Conference on Natural Family Planning, ed. Uricchio and Williams, 35-148. 
by conducting correlational studies with female reproductive hormones and the peak in cervical mucus. ${ }^{37}$ Meanwhile, Dr. Eric Odeblad, a Swedish physician and scientist, was conducting research and classifying cervical mucus apart from the work of the Billings. Eventually, he joined with the Billingses to help provide a scientific foundation for the ovulation method and, in particular, the functions of cervical mucus in reproduction. ${ }^{38}$

In the mid-1960s, Dr. Gabriele Bonomi (Italy) also developed and published a mucus-only method of NFP. His method was little known outside of Italy due to the lack of promotion. ${ }^{39}$ Bonomi was inspired by the document Humanae vitae and founded the "Humanae vitae Movement" in Italy to educate youth and couples about the value of conjugal love lived according to a natural order designed by God for the good of men and women.

\section{The Papal Birth Control Commission and the Influence of an Inaccurate "Study" (1963-1966)}

After Pius XII died in 1958, the new pope, John XXIII, called the Second Vatican Council to address the concerns of the modern world. Originally, one of the topics to be addressed in the general sessions of the council was that of the transmission of human life. ${ }^{40}$ Archbishop (later Cardinal) Leo Joseph Suenens of Belgium persuaded the Holy Father to take the topic out of the general council and appoint a special commission of theologians and scientists to discuss the issue. John XXIII did not live to see the work of the commission completed. That would be the task of his successor, Paul VI (1963-1978).

The Papal Birth Control Commission met from 1963 to 1966 and grew from six to over seventy-five members. ${ }^{41}$ In 1966 , they completed their task by submitting a majority and a minority report to Paul VI. The majority report recommended that the Church change its teaching on contraception. ${ }^{42}$ The report was not to be shared with others outside of the commission and was meant only for use by the pope. As is now known, some members of the commission leaked the report to the press. ${ }^{43}$ As a result, many expected the Church to change its moral

37 E. L. Billings, J. J. Billings, J. B. Brown, and H. G. Burger, "Symptoms and Hormonal Changes Accompanying Ovulation," The Lancet 299, no 7745 (February 5, 1972): 282-284.

38 Erik Odeblad, "The Discovery of Different Types of Cervical Mucus and the Billings Ovulation Method," Bulletin of the Natural Family Planning Council of Victoria 21, no. 3 (1994): 3-34; Erik Odeblad, "Cervical Mucus and Their Functions," Journal of the Irish Colleges of Physicians and Surgeons 26, no. 1 (1997): 27-32.

39 Gabriele Bonomi, Nuovo Metodo Natural per il Controlle delle Nascite: D'uovo (Brescia: Bailetti, La Chiara, 1968).

40 Robert McClory, Turning Point (New York: Crossroad Publishing Co., 1995), 39-41.

41 McClory, Turning Point, 188-190.

42 Majority Report of the Birth Control Commission, "Responsible Parenthood," in McClory, Turning Point, 171-187.

43 Bernardo Colombo, email communication to author, 1994. Colombo was a professor of biostatistics and sociology at the University of Padua, Italy, and a member of the Birth Control Commission, appointed for the second meeting in 1964. 
teachings on contraception. In the end, as is well known, Paul VI rejected the majority report and promulgated Humanae vitae in 1968.

Despite the majority report, it is interesting to note that among the three married couples appointed to the commission, two of them included Catholic scientists who had contributed to NFP research. These scientists were Drs. Charles Rendu (France) and Laurent Potvin (Canada). Rendu, along with his wife, Elizabeth, was very active in promoting NFP in France and in French-speaking African countries. Potvin, also with his wife, Colette, promoted NFP in Canada. Both couples rejected the majority report and signed the minority report. The third married couple on the commission, Patrick and Patricia Crowley (United States), sided with the majority report. In fact, many of the commission members who signed the majority report were influenced by a flawed survey that the Crowleys had conducted and provided. ${ }^{4}$

The Crowleys, along with Donald Barrett, a professor from the University of Notre Dame, were the cofounders of the Christian Family Movement (CFM). Reporting on the CFM survey to the Commission, Patricia Crowley said that the use of the Rhythm Method was harmful to married life. One of the concerns of the Papal Birth Control Commission was whether the use of natural birth regulation might be harmful to marital relationships. ${ }^{45}$ The Crowley study was not only biased but also flawed scientifically. It provided anecdotal information based on questions which were skewed toward a negative perception of Catholic teaching and the Rhythm Method. While anecdotal experiences by users of the Rhythm Method can provide some understanding of how Rhythm affected the marital bond, anecdotes and biased surveys are often misleading and can give a false perspective. ${ }^{46}$ When done correctly, large scientifically studied populations can provide a broader picture of reality and give a person more confidence in proclaiming both benefits and deficits. In any case, the Crowley study was not a valid scientific report.

One of the first serious academic studies on how NFP affects marital relationships was conducted and published in 1970 by Drs. John Marshal and Beverley Rowe. ${ }^{47}$ Marshall was one of the original members of the Papal Birth Control Commission. He and Rowe were concerned that the practice of NFP (i.e., in the form of BBT) and the required amount of abstinence for pregnancy avoidance might have a negative effect on marriage. Their study showed that of the 502 couples who responded to their detailed psychological questionnaire, 75 percent

44 See McClory, Turning Point, 86-108. The Crowley study was a central influence on the commission's majority report urging a change in the teaching. See also P. Crowley and P. Crowley, "Report to the Papal Birth Control Commission," (1965/1966), University of Notre Dame Archives.

45 See McClory, Turning Point, 72-74.

46 Richard J. Fehring and Elizabeth McGraw, "Spiritual Responses to the Regulation of Birth: A Historical Comparison," Life and Learning 12 (December 2003): 265-283; Richard J. Fehring, "An Analysis of the Majority Report 'Responsible Parenthood' and its Recommendations on Abortion, Sterilization, and Contraception," Life and Learning 13 (2003): 121-146.

47 J. Marshall and B. Rowe, "Psychological Aspects of the Basal Body Temperature Method of Regulating Births," Fertility and Sterility 21 (1970): 9, 14-19. 
of the wives and 66 percent of the husbands felt their overall use of BBT was satisfactory, and 75 percent of the wives and 74 percent of the husbands felt that the use of BBT was helpful to their marriage. However, 48 percent of the husbands and wives felt that the practice of periodic sexual abstinence was somehow harmful to their marriage.

As mentioned, Marshall also conducted the first effectiveness studies of the combined Rhythm and BBT method of NFP. He showed the total failure rate in those confining coitus to the postovulatory phase of the cycle as 6.6 pregnancies per 100 women-years, while the failure rate of those engaging in coitus in both the preovulatory and postovulatory phases was 19.3. ${ }^{48}$ Marshall and a statistician colleague are also known for developing a formula for calculating the day-specific probabilities of pregnancy and defining the biological fertile window. ${ }^{49}$

Another very early member of the Birth Control Commission was Bernardo Colombo from the University of Padua. ${ }^{50}$ His brother Carlo was a bishop and personal theologian to Paul VI and a later member of the commission. Colombo was involved with multiple studies of NFP throughout his academic career, including studies on the Ovulation Method, comparisons of days of abstinence, day-specific probabilities of pregnancy, and developing a large data set of menstrual cycles that is being used to this day. ${ }^{51}$ Colombo was distraught with the political nature of the Birth Control Commission and that members released the majority report to the press rather than keeping it secret (as they promised) until it was given to the pope. ${ }^{52}$

About the same time as the Birth Control Commission was meeting, another commission was created in the United States. It was called the Commission on Rhythm. ${ }^{53}$ This commission was called after an International Symposium on Rhythm was held in Washington, D.C., in 1964. This symposium was cosponsored by the Family Life Bureau of the National Catholic Welfare Conference. ${ }^{54}$ It was organized at the urging of the Rt. Rev. Msgr. John C. Knott, director of the Family Life Bureau, and the president of the National Federation of Catholic Physicians Guilds, Dr. Clement P. Cunningham. After this symposium, a number

\footnotetext{
48 Marshall, "A Field Trial of the Basal-Body-Temperature Method of Regulating Births," 8.

49 J. C. Barrett and J. Marshall, "The Risk of Conception on Different Days of the Menstrual Cycle," Population Studies 23, no. 3 (1969): 455-461.

50 McClory, Turning Point, 47-48.

51 B. Colombo, G. Masarotto, and G. Daily, "Fecundability: First Results from a New Data Base," Demographic Research 3 (2000): 5; B. Colombo, A. Mion, K. Passarin, and B. Scarpa, "Cervical Mucus Symptom and Daily Fecundability: First Result of a New Database," Statistical Methods in Medical Research 15, no. 2 (April 2006): 161-180.

52 Carrying on the work of Colombo at the University of Padua is the Catholic biostatistician Dr. Bruno Scarpa. He has participated (and continues to do so) in many NFP studies and conferences. In addition to Scarpa, the biostatistician Dr. Rene Ecochard from the University of Lyon, France, has made significant contributions as well. Ecochard has a consistent record in NFP research and publishing. In addition, he and his wife have been active in promoting NFP in France and other countries.

53 Herbert Ratner, "Commission on Rhythm: Origin of the Commission," The Linacre Quarterly 32, no. 4 (1965): 356-357.

54 Now called United States Conference of Catholic Bishops.
} 
of physicians met in Chicago to continue discussions on the topic of Rhythm and Church teaching and to plan future meetings on the subject. Cunningham also had a personal meeting about the issue with Paul VI in Rome.

The second International Symposium on Rhythm met in Kansas City in 1965 and included a scientific program for physicians. Among the speakers and topics presented were: Dr. Konald Prem (University of Minnesota), speaking on "The Basal Temperature Method of the Practice of Rhythm"; Dr. Max Levin (New York Medical School), on "Sexual Fulfillment in the Couple Practicing Rhythm"; and Dr. Daniel McSweeney (Tufts University School of Medicine), on "The Cervical Mucus Test for the Determination of Ovulation." ${ }^{35}$ Over 300 participants attended the symposium.

Dr. Herbert Ratner (Chicago) reported on the international symposiums in the journal of the National Federation of Catholic Physician Guilds, The Linacre Quarterly. The continued meetings of this planning commission included a mixture of priests and physicians, including department heads of medical schools. The 4th International Symposium on Abortion, Rhythm and Life was held in 1969 in Chicago. ${ }^{56}$ As indicated by the title, the commission took on a broader role that included the rising issue of abortion and other threats to family life and marriage. Of significance is that this commission initiated a new journal Child and Health with Ratner as chief editor. The journal included articles on Rhythm, pro-life subjects, and family topics.

\section{Post-Humanae vitae NFP Scientists (1968-2005)}

By the time Humanae vitae was promulgated, most of the major systems of NFP were already developed and studied. ${ }^{57}$ In fact, twenty years later in 1988 , Dr. Claude Lanctot, a Catholic physician scientist from Canada, indicated at an international NFP conference in Hong Kong that the NFP pioneer phase was already completed. He noted that during the years 1955-1970, the modern methods of NFP were developed..$^{58}$ The next phase, covering the years $1970-1988$, was what he called the "popularization phase" or what could be referred to as the program development, marketing, and scaling-up phase.

Soon after Humanae vitae was promulgated, the Catholic bishops in the United States provided funds for the development of The Human Life Foundation (later called the Human Life and Natural Family Planning Foundation), which was to be an independent, nonsectarian organization dedicated to pursue research essential

55 Herbert Ratner, "Commission on Rhythm: The 2nd International Symposium on Rhythm," The Linacre Quarterly 33, no. 1 (1966): 310.

56 Herbert Ratner, "National Commission on Human Life Reproduction and Rhythm," The Linacre Quarterly36, no.1 (1969): 77-78.

57 The methods are the calendar methods, Sympto-Thermal methods, and the newer cervical mucus-only methods.

58 Claude Lanctot, "Historical Background of Natural Family Planning," in Proceedings of the International Seminar on Natural Family Planning and Family Life Education, eds. Ramon C. Ruiz, John Russell, and Irene Osmund Ruiz (Hong Kong: Hong Kong University Press, 1988), 1-10. 
to the improvement of NFP ${ }^{59}$ The first Scientific Advisory Committee of this foundation included six scientists with doctorate degrees and ten physicians who were either full professors at a university or department chairs of medicine. One of the first projects for this group was to organize and present an international conference on NFP, commonly referred to as the Arlie House Conference. ${ }^{60}$ Of significance is that this might have been the first major conference that used the term "Natural Family Planning." A physician scientist from the National Institutes of Health (NIH) suggested using the term "Natural Family Planning." The conference was partially funded by the NIH Center for Population Research and National Institute of Child Health and Human Development. ${ }^{61}$ The proceedings were published and included nineteen papers and discussion from fifty-nine conferees who came from eight countries. There were presentations on three of the newer NFP methods, namely, BBT, STM, and the Ovulation Method. Of note was the presentation of papers on psychological and sociological implications of family planning as well.

Among the participants at this conference were Drs. Gerard Döring and John Marshall, developers of the temperature method (BBT); John and Evelyn Billings, developers of the new Ovulation Method; and Lanctot, one of the researchers and promoters of the STM in Canada and the United States. ${ }^{62}$ In 1972, what became known as the Billings Ovulation Method ${ }^{\circledR}\left(\mathrm{BOM}^{\circledR}\right)$ was just being introduced in the United States. The sense at the conference was that this method had a lot of potential for a simple approach that provided a natural indicator for the beginning, peak, and end of the fertile phase. Although as mentioned, another Catholic physician, Bonomi, developed a single mucus indictor method in the 1960s and published a book in Italian, it seems that the BOM is the one that took off and generated the most optimism at that time, probably because it was introduced to the United States, Canada, and other developed English-speaking countries around the world. In addition, the BOM received federal and international funding for large multi-country studies.

After the 1972 Arlie House conference, a number of effectiveness studies of the BOM were conducted and published, including one in the United States that was led by Sr./Dr. Hanna Klaus at Saint Louis University School of Medicine. ${ }^{63}$ Klaus, a Catholic physician, obstetrician, and gynecologist as well as a religious missionary sister, dedicated her life to promoting NFP. Her study is the first effectiveness study of the Billings Ovulation Method ${ }^{\circledR}$ in the United States. ${ }^{64}$

59 Larry Kane, "NFP Pioneers: Human Life and NFP Foundation," NFP-Diocesan-Activity-Report 5, no. 4 (1994): 6-7.

60 See Uricchio and Williams, eds., Proceedings of a Research Conference on Natural Family Planning, xvii-xviii.

61 Kane, "NFP Pioneers: Human Life and NFP Foundation," 6-7.

62 Uricchio and Williams, eds. Proceedings of a Research Conference on Natural Family Planning, xxiii-xxv.

63 H. Klaus, J. M. Goebel, B. Muraski, M. T. Egizio, D. Weitzel, R. S. Taylor, M. U. Fagan K. Ek, and K. Hobday, "Use Effectiveness and Client Satisfaction in Six Centers Teaching the Billings Ovulation Method," Contraception 19, no. 6 (1978): 613-629.

64 Later, at the request of the Billingses, Klaus also turned her attention to investigate and develop programs that integrate fertility knowledge with chastity education for adolescents. She eventually developed 
In the 1970s, interest in the Billings Ovulation Method ${ }^{\circledR}$ and the Sympto-Thermal Method stimulated federal funding for two randomized comparison studies in Columbia and the United States. ${ }^{65}$ Dr. William A. Uricchio, a Catholic scientist and past president of the Human Life Foundation, was one of the main organizers of the comparison study conducted in the United States. At this time, and probably the most famous research of the Billings Ovulation Method ${ }^{\circledR}$ is the five-country effectiveness study that was funded by the World Health Organization (WHO) and the United States Aid to International Development (USAID) ${ }^{66}$

The STM was promoted and studied by Lanctot along with Dr. Suzanne Parenteau-Carreau, also a Catholic physician from Canada. ${ }^{67}$ The STM became a standard method and program of NFP through an organization called SERENA. The SERENA program began in the 1950s based on the CLER program in France that was developed and led by Rendu, the Catholic scientist and gynecologist who was a member of the Papal Birth Control Commission, and with the early pioneers and promoters of NFP, Drs. Michele and Francois Guy from Grenoble, France. Parenteau-Carreau is a long-time medical patron, consultant, researcher, and scientist associated with SERENA. ${ }^{68}$

Over the years, there emerged a number of variants of the Billings Ovulation Method ${ }^{\circledR}$. In the early 1970 s, Klaus and a young Catholic physician obstetrician gynecologist, Dr. Thomas Hilgers, worked at the University of Saint Louis School of Medicine. Klaus was involved with an NFP federal grant proposal that was written to study the $\mathrm{BOM}^{\circledR}$. It eventually was funded with Hilgers as the principal investigator. Hilgers conducted a number of studies on cervical mucus and other indicators of fertility. From his work, along with contributions from his wife, Susan, and two Catholic professional nurses, Diane Daly and Ann Prebil, ${ }^{69}$ he developed a cervical mucus-based system

the TeenSTAR (Sexuality Teaching in the context of Adult Responsibility) program, which was studied and then promoted worldwide. See H. Klaus, "Abstinence and Abstinence-only Education," Journal of Adolescent Health 39, no. 2 (2006): 151-154 and H. Klaus, L. M. Bryan, M. L. Bryant, U. Fagan, M. B. Harrigan, F. Kearns, "Fertility awareness/natural family planning for adolescents and their families: report of multisite pilot project," International Journal of Adolescent Medical Health 3, no. 2 (1987): 101-119.

65 M. E. Wade, P. McCarthy, J. R., Abernathy, G. S., Harris, H. S. Danzer, and W. A. Uricchio, "A Randomized Prospective Study of the Use-Effectiveness of Two Methods of Natural Family Planning: An lnterim Report," American Journal of Obstetrics and Gynecology 134, no. 6 (1979): 628-631; M. E. Wade, P. McCarthy, G. D., Barunstein, J. R. Abernathy, C. M. Suchindran, G. S. Harris, H. C. Danzer, and W. A. Uricchio, "A Randomized Prospective Study of the Use Effectiveness of Two Methods of Natural Family Planning," American Journal of Obstetrics and Gynecology 141, no. 4 (1981): 368-376; J. E. Medina, A. Cifuentes, J. R. Abernathy, J. M. Spieler, and M. E. Wade, "Comparative Evaluation of Two Methods of Natural Family Planning in Columbia," American Journal of Obstetrics and Gynecology 138, no. 8 (1980): 1142-1147.

66 World Health Organization, "A Prospective Multicentre Trial of the Ovulation Method of Natural Family Planning, 11: The Effectiveness Phase," Fertility and Sterility 36, no. 5 (November 1981): 591-598.

67 F. J. Rice, C. A. Lanctot, and D. Garcia-Devesa, "Effectiveness of the Sympto-Thermal Method of Natural Family Planning: An International Study," International Journal of Fertility 26, no. 3 (1981): 222-230; Suzanne Parenteau-Carreau, "The Sympto-Thermal Methods," International Journal of Fertility 26, no. 3 (1981): 170-181.

68 Suzanne Parenteau-Carreau, Planning Your Family the S-T Way (Ottawa: SERENA Canada, 1977).

69 T. W. Hilgers, G. E. Abraham, and D. Cavanagh, "Natural Family Planning 1. The Peak Symptom and Estimated Time of Ovulation," Obstetrics and Gynecology 52, no. 5 (November 1, 1978): 575-582; T. W. Hilgers, K. D. Daly, A. M. Prebil, and S. K. Hilgers, "Cumulative Pregnancy Rates in Patients 
of NFP that is now called the Creighton Model FertilityCare ${ }^{\mathrm{TM}}$ system, or the Creighton Model.

The Creighton Model is a form of the Ovulation Method that uses a standardized mucus rating, couple teaching program, menstrual cycle charting, follow-up, and pregnancy evaluation. Hilgers moved to Creighton University School of Medicine in Omaha, Nebraska, where he was an associate professor of medicine and founder of the Creighton University Natural Family Planning Education and Research Center. He and his wife eventually started their own independent institute named after and dedicated to Paul VI. ${ }^{70}$ Hilgers is also known for the development of what is called NaProTECHNOLOGY, ${ }^{\mathrm{TM}}$ a system of woman's health care that integrates the use of the Creighton Model (CrM) into medical treatment protocols. ${ }^{71}$

An additional example of an NFP method that is based on the work of the Billingses can be seen in the Modified Mucus Method, developed by Dr. Kathleen Dorairaj, a Catholic physician from India. This simplified form of the Ovulation Method was specifically designed for the indigent population in India. ${ }^{72}$

The Human Life and Natural Family Planning Foundation was instrumental in promoting and facilitating NFP in the United States. One of the members of the foundation was Mary Catherine Martin, who received her doctorate in nursing from The Catholic University of American in Washington, D.C. Martin's doctoral dissertation treated the development of an NFP teacher training program and teaching materials. ${ }^{73}$ Through her efforts and the funding of the Human Life and NFP Foundation, booklets were published on NFP including reproductive graphics that were used in many diocesan and regional NFP teaching programs. These materials also became the bases for the NFP materials used in the WHO multicountry study of the BOM ${ }^{\circledR}{ }^{74}$

In 1974, the president of the United States National Federation of Catholic Physician Guilds was Dr. John Brennan, an obstetrician and gynecologist from Milwaukee. Brennan wrote a letter to every member of the federation and provided each with a Billings booklet. ${ }^{75} \mathrm{He}$ encouraged the members to

With Apparently Normal Fertility and Fertility-Focused Intercourse," Journal of Reproductive Medicine 37, no. 10 (1992): 864-866; see also T. W. Hilgers and J. B. Stanford, "Creighton Model NaProEducation Technology for Avoiding Pregnancy: Use Effectiveness," The Journal of Reproductive Medicine 43, no. 6 (June 1998): 495-502.

70 The Pope Paul VI Institute for the Study of Human Reproduction.

71 Thomas W. Hilgers, The Medical Applications of Natural Family Planning (Omaha: Pope Paul VI Institute Press, 1991); Thomas W. Hilgers, The Scientific Foundations of the Ovulation Method (Omaha: Pope Paul VI Institute Press, 1995); Thomas W. Hilgers, The Creighton Model NaProEducation System (Omaha: Pope Paul VI Institute Press, 1996).

72 Kathleen Dorairaj, "The Modified Mucus Method," in Proceedings of the International Seminar on Natural Family Planning and Family Life Education, ed. Ramon C. Ruiz, John Russell, and Irene Osmund Ruiz, (Hong Kong: Hong Kong University Press, 1988), 53-60.

73 Mary Katherine Martin, "NFP Pioneers: NFP Teacher Training and Service Development Efforts-1974-1985," NFP-Diocesan-Activity-Report 6, no. 1 (1995): 10-11.

74 Martin, "NFP Pioneers" 10-11.

75 John Brennan, "What Can the Doctor Do?" in A Reader in Natural Family Planning. Report on International Conferences, ed. Anthony Zimmerman (Collegeville, Minn.: The Human Life Center), 59. 
have copies of the booklet for their patients (at that time it cost only 20 cents). Brennan was also an officer of the Human Life and Natural Family Planning Foundation and member of the World Organization of the Ovulation Method Billings (WOOMB).

About the same time that Brennan was encouraging the use of NFP among Catholic physicians in the United States, Paul VI continued to plead for research and scholarship on natural methods of birth regulation. In a speech given in 1974 to the $25^{\text {th }}$ General Assembly of Pharmacology, the Holy Father again invited health professionals to deepen and broaden their knowledge about the Church's teaching on the grave question which, at the deepest level, concerns the "concept of man."76 Towards the end of his pontificate in 1977, in an allocution to the Congress of the International Federation of Family Life Promotion, Paul VI stated the importance of the knowledge of the biological laws of human fertility which can enhance a healthy regulation of births by natural methods. He stressed the need for more scientific research in NFP by stating that "scientific research be intensified in this area." ${ }^{77} \mathrm{He}$ also said that the scientific work should be coordinated and supported with funds which are proportionate to the issue in question and to the services rendered. Paul VI died in 1978.

\section{NFP Scientists During John Paul II's Papacy (1978-2005)}

John Paul II greatly expanded the Church's reflection on the understanding of human sexuality as designed by God and the methods of NFP as ethical support for married couples. He did this in many ways, notably through the development of the Theology of the Body $;^{78}$ addresses to promoters of NFP and nurse midwives; the apostolic exhortation Familiaris consortio ${ }^{79}$ and in particular, through the encyclical Evangelium vitae. ${ }^{80}$ Early in his pontificate (November 3, 1979), he provided encouragement to the growing number of physicians and scientists addressing NFP "since at stake is the welfare of families and of societies in their legitimate concern to harmonize human fertility with their capabilities." ${ }^{11}$ A few months later, on January 26, 1980, he addressed midwives, emphasizing the important contribution they make

\footnotetext{
76 Pope Paul VI, To Participants in the Twenty Fifth General Assembly of Pharmacology, September 7, 1974, in Natural Family Planning: Nature's Way-God's Way, ed. Zimmerman, 257.

77 "Letter of Cardinal Villot in the name of Pope Paul VI to the Congress of the International Federation for Family Life Promotion, June 1977," in Natural Family Planning: Nature's Way-God's Way, ed. Zimmerman, 257-258.

78 See http://www.usccb.org/nfp/catholic-teaching/theology-of-the-body.cfm.

79 See Pope John Paul II, Apostolic Exhortation Familiaris consortio (November 22, 1981), http:// w2.vatican.va/content/john-paul-ii/en/apost_exhortations.index.html.

80 Pope John Paul II, Encyclical Letter Evangelium vitae (March 25, 1995), http://w2.vatican.va/content /john-paul-ii/en/encyclicals.index.html.

81 Pope John Paul II, Address to Promoters of Natural Family Planning (January 26, 1980), in Natural Family Planning: Nature's Way-God's Way, ed. Zimmerman, 258-259.
} 
in providing advice and practical guidance to couples wishing to carry out responsible procreation. ${ }^{82}$

In Familiaris consortio, John Paul II asked that scholars explain the moral and anthropologic differences between contraception and natural birth regulation. ${ }^{83}$ In Evangelium vitae, he notes that the moral law obliges couples "in every case to control the impulse of instinct and passion, and to respect the biological laws inscribed in their person." ${ }^{44}$ John Paul II said that "[i]t is precisely this respect which makes legitimate, at the service of responsible procreation, the use of natural methods of regulating fertility." ${ }^{15} \mathrm{He}$ also mentioned the effectiveness of NFP methods when he stated that an "honest appraisal of their effectiveness should dispel certain prejudices which are still widely held, and should convince married couples, as well as health care and social workers, of the importance of proper training in this area ${ }^{86} \mathrm{~A}$ main concern in this encyclical is the desire to build, what John Paul II calls, a "Culture of Life." It involves the implementation of long-term practical projects and initiatives inspired by the Gospel. John Paul II gives direction to this effort by saying, "At the first stage of life, centres for natural methods of regulating fertility should be promoted as a valuable help to responsible parenthood, in which all individuals, and in the first place the child, are recognized and respected in their own right. ${ }^{87}$

The Holy Father continues and notes that a unique responsibility belongs to health-care personnel-doctors, pharmacists, nurses, chaplains, men and women religious, administrators and volunteers. He sees that the work of education in the service of life involves the training of married couples in responsible procreation. ${ }^{8}$ John Paul II especially calls upon intellectuals to build a new culture, with a specific challenge to Catholics, "who are called to be present and active in the leading centres where culture is formed, in schools and universities, in places of scientific and technological research, of artistic creativity and of the study of man." ${ }^{\text {Ap }}$ Apropriate contributions should come from universities, particularly from Catholic universities, centers and institutes..$^{90}$

\section{University-Based NFP Scientists}

Georgetown University: In the mid-1980s, Dr. John Queenan, a Catholic professor of obstetrics and gynecology and chair of the Department of Obstetrics and Gynecology at Georgetown University School of Medicine, was instrumental

\footnotetext{
82 Pope John Paul II, Address to Midwives (1980), in Natural Family Planning: Nature's Way-God's Way, ed. Zimmerman, 259-260.

83 Pope John Paul II, Familiaris consortio, 32.

84 Pope John Paul II, Evangelium vitae, 97.

85 Pope John Paul II, Evangelium vitae, 97.

86 Pope John Paul II, Evangelium vitae, 97.

87 Pope John Paul II, Evangelium vitae, 88.

88 Pope John Paul II, Evangelium vitae, 89.

89 Pope John Paul II, Evangelium vitae, 98.

90 See Pope John Paul II, Evangelium vitae, 98.
} 
in obtaining a multimillion-dollar grant from USAID and WHO to start the Institute for International Studies in Natural Family Planning ${ }^{91}$ at Georgetown University, which was associated with the department of obstetrics and gynecology. ${ }^{92}$ From its inception, Georgetown's NFP institute would be secular in nature despite being associated with a Catholic university. ${ }^{93}$ This approach was due to the requirements of the USAID grant. In addition, its mandate was to research the natural methods and provide programming in developing nations. Dr. Victoria Jennings, a non-Catholic and specialist in Public Health, was named the executive director.

The staff from Georgetown's Institute for International Studies in NFP became involved in a significant project in 1988. They met with experts on breastfeeding and fertility in Bellagio, Italy. The group of experts developed a consensus report on fertility and breastfeeding. Based on the research, they agreed on several principles for effective pregnancy avoidance when a woman breastfeeds: total breastfeeding, has no menstrual bleeding, and is within the first six months of the birth of her child. If a postpartum and breastfeeding woman meets the three criteria, then she has a less than 2 percent chance of pregnancy when engaging in intercourse. This became known as the Bellagio Consensus. The method it produced is called the Lactational Amenorrhea Method (or LAM). ${ }^{94}$

In 1990, Georgetown's NFP institute sponsored a large international conference at the university. The proceedings were published in two parts: the first as a supplement to the American Journal of Obstetrics and Gynecology $y^{95}$ and the second

91 The Institute was founded in 1985. It was renamed the Institute for Reproductive Health in the 1990s.

92 John T. Queenan, “Welcoming Remarks by John T. Queenan," in Natural Family Planning: Current Knowledge and New Strategies for the 1990s. Proceedings of a Conference, Part 11, Georgetown University, Washington, DC, December 10-14, 1990, ed. John T. Queenan, Victoria H. Jennings, Jeffery M Spieler, and Helena von Hertzen (Washington, D.C.: Georgetown University Institute for International Studies in Natural Family Planning, 1991), 4. This conference was cosponsored by Georgetown's Institute for International Studies in Natural Family Planning, the United States Agency for International Development, and the World Health Organization.

93 Over the years, the scientists at Georgetown's institute have adhered to family planning research regulations, such that they followed that discipline's definitions of fertility awareness-based methods (FABMs), effectiveness rates, and recommendations for avoidance of sexually transmitted infections by referring to "unprotected" sexual intercourse in their materials. At the same time, they have made contributions to the viability of natural methods, notably, their attempts to simplify the methods with their Standard Days and Two-Day methods. Unfortunately, in recent years, they also included the option of condom-use during the fertile phase of the menstrual cycle if clients choose that behavior. That was not part of their original mandate when they were founded. It also places their methods into the category of "combined methods"-those natural methods which also make use of barriers-rather than authentic NFP methods.

94 World Health Organization Task Force, "The World Health Organization Multinational Study of Breast-feeding and Lactational Amenorrhea. 111. Pregnancy during breast-feeding," Fertility and Sterility 72 (September 1999): 431-439.

95 John T. Queenan, Victoria H. Jennings, Jeffery M Spieler, and Helena von Hertzen, eds., Natural Family Planning: Current Knowledge and New Strategies for the 1990s. Proceedings of a Conference, Part 1, "Supplement," American Journal of Obstetrics and Gynecology (St Louis: Mosby-Year Book, Inc., 1991). 
published by the institute itself. ${ }^{96}$ The conference included a "Who's Who" in NFP, including representatives from NFP programs from thirty-one countries and five continents. The conference focused on the scientific experts in the physiology of reproduction, NFP method updates and effectiveness, and the breastfeeding transition to fertility and the use of NFP. At this conference, a number of scientific papers were presented on the lactational amenorrhea method and the use of NFP during the postpartum breastfeeding transition to fertility.

Marquette University: In the early 1980s, Brennan approached Dr. Richard Fehring, a young Catholic scientist and assistant professor at Marquette University who received his doctorate in nursing science at The Catholic University of America, to start an NFP training program at Marquette University College of Nursing. Fehring explored a number of existing NFP teacher training programs and eventually attended the Creighton University program under the direction of Hilgers. In 1985, Fehring and other faculty at Marquette started providing NFP services through the College of Nursing and at the Catholic Hospitals in Milwaukee. Fehring became the president of the American Academy of Natural Family Planning (AAFNP) ${ }^{97}$ in 1990 and published one of the first effectiveness studies of the Creighton Model. ${ }^{98}$

In 1998, Dr. Fehring started what is now called the Marquette University Institute of NFP and, with other Catholic professional nurses (in particular Mary Schneider and Susana Crespo), and Catholic physicians, developed a new system of NFP that integrates hormonal monitoring technology. They named the new system the Marquette Model (MM) of NFP.99 In 2000, a for-credit NFP teacher training program for health professionals was approved and launched at Marquette University and in 2001 it became an all-online access program.

Fehring became a member of the National NFP Advisory Board of the USCCB and writer-editor of Current Medical Research in NFP published by the USCCB. In cooperation with Dr. Theresa Notare, assistant director of the Natural Family Planning Program at the USCCB, Fehring and others at the Marquette University Institute for NFP developed, presented, and published proceedings of three national scholarly conferences on NFP. ${ }^{100}$

96 Queenan, et al., ed., Natural Family Planning: Current Knowledge and New Strategies for the 1990s. Proceedings of a Conference, Part 11.

97 The accrediting and certification association of Creighton Model education centers and teachers. The AANFP later changed its name to the American Association of FertilityCare ${ }^{\mathrm{TM}}$ Professionals.

98 R. J. Fehring, D. Lawrence, and C. Philpot, "Use-Effectiveness of the Creighton Model Ovulation Method of Natural Family Planning," Journal of Obstetric, Gynecologic, and Neonatal Nursing 23, no. 4 (1994): 303-309.

99 R. J. Fehring, M. Schneider, and K. Raviele, "Efficacy of Hormonal Fertility Monitoring as a Method of Natural Family Planning," Journal of Obstetric, Gynecologic, and Neonatal Nursing 36, no. 2 (2007): $152-160$.

100 Richard J. Fehring and Theresa Notare, eds., Integrating Faith and Science Through Natural Family Planning (Milwaukee: Marquette University Press, 2004); Richard J. Fehring and Theresa Notare, eds., Human Fertility: Where Faith and Science Meet (Milwaukee: Marquette University Press, 2008); Richard J. Fehring and Theresa Notare, eds., Science, Faith, and Human Fertility: The Third Conference on Ethical Fertility Health Management (Milwaukee: Marquette University Press, 2012). 
Dr. Mary Lee Barron, a Catholic professor and advanced practice nurse at Saint Louis University School of Nursing, was one of the early developers of the MM. She collaborated in research studies on the MM and, in particular, the MM studies on the breastfeeding transition. ${ }^{101}$ Barron also developed an NFP education clinic at Saint Louis University. Another significant Catholic physician that was involved with the early development of the MM is Dr. Kathleen Raviele. ${ }^{102}$ More recently, Dr. Thomas Bouchard, a family medicine physician associated with the University of Calgary and past president of the Canadian Federation of Catholic Physicians, is an MM provider and has conducted a number of MM effectiveness studies with other scientists at the Marquette University NFP Institute. ${ }^{103}$

Germany: During the 1980s in Germany, the development of NFP was based on followers of Rötzer and a group of German scientists and promoters of NFP who started the NFP Arbeitsgruppe (work group) for the collection of data for NFP projects and the development of NFP teachers and programs. ${ }^{104}$ In 1985 , the group received funding from the German Federal Ministry for Youth, Family, Women and Health for further studies in NFP and for development of NFP programs. The scientific part of this group was situated, at first, at the University of Dusseldorf and then in 2007 at the University of Heidelberg. The scientific leader of this group was professor Dr. Guenter Freundl, a retired professor of the Department of Obstetrics and Gynecology at the University Düsseldorf. Freundl is a dedicated Catholic scientist and principal investigator for many research projects on NFP since $1984 .{ }^{105}$ The current section leader for NFP research is Dr. Petra Frank-Herrmann, a Catholic physician and lecturer at the University of Heidelberg. ${ }^{106}$ The German work group on NFP and its scientific arm is one

101 Mary Lee Barron and Richard J. Fehring, "Basal Body Temperature Recording: A Useful Recommendation to Couples Seeking Pregnancy?" Journal of Maternal Child Nursing 30, no. 5 (2005): 290-296 and Richard J. Fehring, Mary Schneider, and Mary Lee Barron, "Protocol for Determining Fertility while Breastfeeding," Fertility and Sterility 84, no. 3 (2005): 805-807. Dr. Raviele was also the first female president of the Catholic Medical Association.

102 Some of her publications include: Fehring, Schneider, and Raviele, "Efficacy of Hormonal Fertility Monitoring"; Richard J. Fehring, Mary Schneider, and Kathleen Raviele, "Pilot Evaluation of an Internet-based Natural Family Planning Education and Service Program," Journal of Obstetric, Gynecologic, and Neonatal Nursing 40 (2011): 281-291; Richard J. Fehring, Mary Schneider, Kathleen Raviele, Dana Rodriguez, and Jessica E. Pruszynski, "Randomized Comparison of Two Internet-Supported Fertility Awareness Based Methods of Family Planning," Contraception 88, no. 1 (July 2013): 24-30.

103 Thomas P. Bouchard, Mary Schneider, and Richard J. Fehring, "Efficacy of a New Postpartum Transition Protocol for Avoiding Pregnancy," Journal of the American Board of Family Medicine 26, no. 1 (2013): 35-44; Thomas P. Bouchard, Richard J. Fehring, and Mary M. Schneider, "Achieving Pregnancy Using Primary Care Interventions to ldentify the Fertile Window," Frontiers in Medicine 4, art. 250 (January 9, 2018): 1-7.

104 Elizabeth Raith-Paula, Petra Frank-Herrmann, Günter Freundl, and Thomas Strowitzki. Natürliche Familienplanung heute (Natural Family Planning Today), 4th Edition (Heidelberg, Germany: Springer, 2008), 13.

105 G. Freundel, A. Flynn, P. Frank-Herrmann, and C. Gnoth, "European Multicenter Study of Natural Family Planning (1989-1995): Efficacy and Drop-Out," The European Natural Family Planning Study Groups, Advances in Contraception 15, no. 1 (1999): 69-83.

106 P. Frank-Herrmann, J. Heil, C. Gnoth, E. Toledo, S. Baur, C. Pyper, E. Jenetzky, T. Strowitzki, and G. Freundl, "The Effectiveness of a Fertility Awareness-Based Method to Avoid Pregnancy in Relation to a 
of the most prolific and consistent research teams in the world. Both Freundl and Frank-Herrmann are noted for their effectiveness studies on the European Double Check Method of NFP, investigating the accuracy of fertility monitors, and integrating NFP with women's health.

Italy: In 1988, three Rome-based medical universities and two pontifical universities presented a conference dedicated to the scientific developments for the twentieth anniversary of Humanae vitae. ${ }^{107}$ This conference had scientists from England, Europe, German, Italy, and Australia, and it included a number of articles on breastfeeding and fertility, demographics of family planning, and also development of new technology in determining the fertile period of the menstrual cycle.

\section{Fertility Monitors}

In 1990, Carl Djerassi, one of the developers of the early progesterone hormonal birth control pill in the United States, predicted that women would be able to monitor their own hormones in order to determine the fertile and infertile times of their menstrual cycles. He called this new method "Jet Age" Natural Family Planning. ${ }^{108}$ In the late 1990s, Djerassi's "prediction" seemed to be realized with the introduction of two electronic fertility hormonal monitors.

The first hormonal monitor was produced by Unipath Ltd. (Bedford, England). Called the "Persona," the monitor's purpose was to help women determine their window of fertility in order to avoid pregnancy. The second monitor that was developed was the Clearplan Easy Fertility Monitor (now called the Clearblue ${ }^{\circledR}$ Fertility Monitor, or CBFM). Clearplan Easy Fertility Monitor was developed for couples choosing to achieve a pregnancy. ${ }^{109}$

A number of Catholic scientists conducted a study on the effectiveness of the Persona, including Drs. Freundl at the University of Dusseldorf, John Bonner from Trinity University in Ireland, and Anna Flynn from England. ${ }^{10}$ The results from that study enabled Unipath to incorporate a new algorithm for the current Persona that is sold in Europe and Canada.

Regarding the second monitor, health professionals and researchers at Marquette University have incorporated use of the CBFM with other markers of fertility (i.e., cervical mucus and BBT) as an aid to learning and using NFP. ${ }^{11}$ The CBFM is currently used on its own along with a calendar algorithm for women

Couple's Sexual Behavior during the Fertile Time: A Prospective Longitudinal Study," Human Reproduction 22, no. 5 (2007): 1310-1319.

107 P. F. A. Van Look and S. Mancuso, "Natural Fertility Regulation Today," International Journal of Gynecology and Obstetrics, Supplement 1 (1989).

108 C. Djerassi, "Fertility Awareness: Jet-Age Rhythm Method?” Science 248 (June 1, 1990): 1061-1062.

109 K. May, "Home Monitoring with the ClearPlan Easy Fertility Monitor for Fertility Awareness," Journal of International Medical Research 29 (Suppl 1) (2001): 14A-20A.

110 J. Bonnar, A. Flynn, G. Freundl, R. Kirkman, R. Royston, and R. Snowden, "Personal Hormone Monitoring for Contraception," British Journal of Family Planning 24, no. 4 (1999): 128-134.

111 Fehring, Schneider, and Raviele, "Efficacy of Hormonal Fertility Monitoring." 
and couples who want a simple, fast, objective, and accurate means to determine the fertile and infertile phases of the menstrual cycle.

In addition to the above, in the early 1990s, Brown (Australia) developed an ovarian monitor for the purpose of having a home use device that measured hormonal profiles of estrogen and progesterone throughout the menstrual cycle. ${ }^{112}$ The monitor utilizes a timed three-hour urine collection that is diluted to 150 $\mathrm{ml}$. Samples of the urine are placed in pre-coated assay tubes and then read by the monitor. The monitor is based on homogenous enzyme immunoassay principles and is designed to measure estrone glucuronide $(\mathrm{E} 1 \mathrm{G})$ and pregnanediol glucuronide (PdG) levels.

The home use Ovarian Monitor has been in development for over twenty years primarily under the influence of Drs. Brown and Len Blackwell (New Zealand). The Ovarian Monitor is designed to measure urinary assays of estrone glucuronide $(\mathrm{E} 1 \mathrm{G})$ and pregnanediol glucuronide $(\mathrm{PdG})$ as measures of ovarian activity during a woman's menstrual cycle. Researchers from New Zealand, Australia, and Chile ${ }^{113}$ continue to research, develop, and study the accuracy and reliability of the Ovarian monitor in comparison to those found in a laboratory. ${ }^{114}$ Fertility monitors are among the innovative approaches to NFP education and hold the promise of providing more precise information to a woman about her window of fertility.

\section{NFP Scientists during the Papacies of Benedict XVI and Pope Francis (2005-2018)}

When John Paul II died in 2005, it was an uncertain time for those who felt his presence and support for NFP science. There was great anticipation for the new pope and his direction for the future of life issues and NFP. The NFP science community was grateful that Pope Benedict XVI supported their work. When he retired, he expressed gratitude to NFP researchers working on ways to combat sterility and said scientists "are to be encouraged to continue their research with the aim of preventing the causes of sterility and of being able to remedy them, so that sterile couples will be able to procreate in full respect for their own personal dignity and that of the child to be born."115

112 J. B. Brown, J. Holmes, and G. Barker, "Use of the Home Ovarian Monitor in Pregnancy Avoidance," American Journal of Obstetrics and Gynecology 165, no. 6 (1991): 2008-2011.

113 In particular, two Catholic scientists, Len Blackwell from Massy University in New Zealand and Dr. Pilar Vigil from Chile.

114 L. F. Blackwell, P. Vigil, M. E. Alliende, S. Brown, M. Festin, and D. G. Cooke, "Monitoring of Ovarian Activity by Measurement of Urinary Excretion Rates Using the Ovarian Monitor, Part IV: The Relationship of the Pregnanediol Glucuronide Threshold to Basal Body Temperature and Cervical Mucus as Markers for the Beginning of the Postovulatory Infertile Period," Human Reproduction 31, no. 2 (February 2016):445-453.

115 Pope Benedict XV1, Message of His Holiness Benedict XVI on the Occasion of the $40^{\text {th }}$ Anniversary of Paul Vl's Encyclical Humanae vitae, given on October 2, 2008 at the International Congress at the Catholic University of the Sacred Heart, Rome, https://w2.vatican.va/content/benedict-xvi/en/messages/ pont-messages/2008.index.html. 
In his recent apostolic exhortation Amoris laetitia, Pope Francis reiterated the teachings of Humanae vitae, saying that "the use of methods based on the laws of nature and the incidence of fertility' (Humanae vitae, 11) are to be promoted, since 'these methods respect the bodies of the spouses, encourage tenderness between them and favour the education of an authentic freedom' (Catechism of the Catholic Church, no. 2370)."116

\section{Conclusion: Looking Forward}

The Church continues to call for work on the science of NFP and related topics. Many of the current NFP scientists from the post-Humanae vitae era and, in particular, the John Paul II era, are still engaged in NFP research-they are an inspiration. There is also cause for hope in the presence of non-Catholic scientists who have answered that call and recognize the value of the natural methods of NFP and the truth of Catholic teaching expressed in Humanae vitae. One such scientist is Dr. Joseph Stanford, professor of Family Medicine at the University of Utah. Stanford is a man of faith (Latter-Day Saints) and a friend of Catholic teaching on married love, responsible parenthood, and the encyclical Humanae vitae. He is one of the most consistent and active NFP researchers in the world today. He also has presented a number of times at conferences sponsored by the USCCB's NFP Program and the Catholic Medical Association. ${ }^{117}$ It is more than encouraging that a scientist of his caliber has taken up the call of Paul VI to "men of science."

Over the years, there have been hundreds of scientists, Catholic and nonCatholic, who have been involved with the work of understanding human reproduction, discovering natural indicators of fertility, developing new methods of NFP, investigating the effectiveness of these methods, integrating NFP methods with women's health care, and explaining the effects of using these methods on the marital bond. It is impossible to mention each one in this essay. ${ }^{118}$ Yet, this essay is an attempt to pay some small homage to these noble efforts.

Looking ahead, current and future NFP scientists continue to take up the work begun by Knaus, Latz, Smulders, and others in the early 1900s. Some of that work is already promising in the form of new technology for monitoring reproductive hormones, the integration of internet technology and mobile cell phone applications, and the understanding of how the menstrual cycle is a vital sign for women's health. But that is the subject of another essay. For now, it is enough to tell the story of the NFP scientists to encourage and inspire young scientists to take up the task called for in Humanae vitae.

116 Pope Francis, Apostolic Exhortation Amoris laetitia (March 19, 2016), 222, http://w2.vatican.va /content/francesco/en/apost_exhortations.index.html.

117 Joseph B. Stanford, "The Role of Randomized Control Trials in NFP Studies," in Human Fertility: Where Faith and Science Meet, ed. Fehring and Notare, 185-196.

118 For those interested in further reading on these pioneers, see the book by Jan Mucharski, History of the Biological Control of Human Fertility (Oak Ridge, N.J.: Married Life Information, 1982). 